\title{
Extraction of Selected Metals from Waste Printed Circuit Boards by Bioleaching Acidophilic Bacteria
}

\author{
Anna HOEDA ${ }^{1)}$, Aldona KRAWCZYKOWSKA ${ }^{1)}$
}

\footnotetext{
1) AGH University of Science and Technology, Faculty of Civil Engineering and Resource Management, Department of Environmental Engineering, Kraków, Poland
}

http://doi.org/10.29227/IM-2021-01-06

Submission date: 10-01-2021 | Review date: 28-05-2021

\section{Abstract}

Technological innovations and increased demand for electronic devices resulted in production of more and more waste with high metal content. Worldwide, 50 million tons of WEEE (Waste from Electrical and Electronic Equipment) are generated each year. Given the metal content present in electrical waste (e-waste), it is considered to be an urban mine and, if properly treated, can serve as an alternative secondary source of metals. Waste printed circuit boards (WPCBs) that constitute approx. 3-5\% of WEEE by weight are of particular importance. They contain, on average, 30-40\% of metals by weight, with higher purity than in minerals. With environmental and economic benefits in mind, increasing attention is being paid to the development of processes to recover metals and other valuable materials from WPCBs. The research presented in the article aimed at assessing the usefulness of the biotechnological method for leaching of selected metals from e-waste. The results indicate that it is possible to mobilize metals from WPCBs using microorganisms such as Acidithiobacillus ferroxidans bacteria.

Keywords: Acidithiobacillus ferrooxidans, bioleaching, waste printed circuit boards, WPCBs

\section{Introduction}

Innovation in today's economy is increasingly dependent on non-ferrous metals: copper, nickel, silver, lead and others, and rare earth elements (REEs). Alternative power engineering is one of those industries where the consumption of critical and strategic raw materials will grow exponentially in the coming years. Securing stable sources of supply is therefore becoming not only critical to Europe's economic success, but also to its green aspirations and the transition it brings about from an economy dependent on fossil fuels to one based on renewable sources. Growing demand for non-ferrous metals over the past centuries has put constant pressure on natural resources - many of the important and most widely used raw materials that are running out, deposits of readily available and high quality are available. What is more, the extraction and processing of non-renewable raw materials involves interference in the environment (Pollmann et al., 2018; Hołda and Krawczykowska, 2020).

A relevant approach concerning saving resources seems to be recycling. It allows for reusing raw material that has already been exhausted. Waste produced becomes a renewable, secondary source of natural resources which limits its depletion. Moreover, effective recycling provides safe resources for industrialised countries and reduces dependence on resource-rich countries (Hołda and Krawczykowska, 2020).

Currently, the highest growth rate is attributed to WEEE (Waste from Electrical and Electronic Equipment). This is due to the increase in consumer demand for electronics and the affordability and shortened lifespan of electrical and electronic products. Worldwide, 50 million tons of WEEE waste are generated each year, but only less than $20 \%$ of it is recycled (Xia et al., 2018; Sethurajan and Gaydardzhiev, 2021). Given the metal content present in electrical waste (e-waste), it is considered to be an urban mine and, if properly treated, can serve as an alternative secondary source of metals. Continuous innovation of consumer EEE results in highly variable material properties and shape of end products, with increasing complexity. So the elemental composition of the waste is also highly variable and complex. Waste printed circuit boards (WPCBs) that constitute approx. 3-5\% of WEEE by weight are of particular importance. They contain, on average, $30-40 \%$ of metals by weight, with higher purity than in minerals, including base metals $(\mathrm{Cu}, \mathrm{Zn})$, precious metals ( $\mathrm{Au}, \mathrm{Ag}$, Pd) and heavy metals (Isildar et al., 2019, Khatri et al., 2018; Garg et al., 2019; Tipre et al., 2021). However, the percentage of reuse and recovery of the precious components contained in the WPCB is very low. With environmental and economic benefits in mind, increasing attention is being paid to the development of processes to recover metals and other valuable materials from WPCBs.

Conventional technologies including mechanical and chemical methods can be used to extract metal from e-waste. However, WPCB recycling processes by pyrometallurgical or hydrometallurgical methods generate atmospheric pollution due to the release of dioxins and furans, and generate large amounts of wastewater. Moreover, such processes are costly due to high energy consumption and should not be considered the most economical way to extract valuable components from WPCBs ( Zhang et al., 2012; Hao et al., 2020; Kaya 2017; Li et al., 2018; Lu and Xu, 2016; Akcil et al., 2015; Cui and Zhang, 2018; Bosecker, 2006; Krebs et al., 2006). Therefore, it seems that biohydrometallurgical methods which can be described as ecological, inexpensive, "low-tech" processes with low emission of hazardous substances, using naturally occurring microorganisms and their metabolic products to extract metals from the matrix, have a chance to be applied on an industrial scale. These methods have already been successful in the processing of low-quality ores and bioleaching of in- 


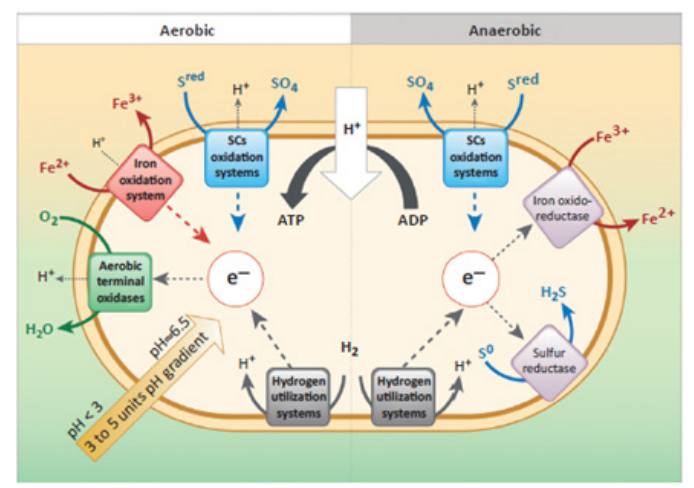

Fig. 1. Oxidation/reduction reactions carried out by A. ferrooxidans (Quatrini and Johnson, 2019) Rys. 1. Reakcje utleniania/redukcji z udziałem bakterii A. ferrooxidans (Quatrini and Johnson, 2019)

dustrial solid waste (Xia et al., 2018; Pollmann et al., 2018; Zhuang et al.,2015; Awashti et al., 2019). The applicability of bacteria in the extraction of metallic elements from waste is directly related to their participation in the biogeochemical cycle of metals in the environment. Obviously, important factors influencing the transition of metals from insoluble to soluble forms are abiotic factors such as $\mathrm{pH}$, oxidoreduction potential, ionic strength or form of metal occurrence, but in addition to important physico-chemical conditions, biotic factors play an important role. Among them, the microorganisms capable of easily adapting to extreme conditions (high concentrations of heavy metals) and of using metals as a source of energy or as final electron acceptors are the most important. It is the by-products of bacterial metabolic processes (energy-transducing processes) such as ferric iron ions (ferric iron) and sulfuric acid(VI) that mobilize metals in the environment, including toxic metals (Valdes et al., 2008).

The microorganisms involved in the process of bioleaching of WPCBs are mainly chemoautothrops Acidithiobacillus ferrooxidans, Acidithiobacillus thiooxidans (Brandl et al., 2001; Hong and Valix, 2014; Yang et al., 2014; Wilner and Fornalczyk, 2013; Blazek et al., 2012), iron-oxidizing bacteria and sulfur bacteria (Wang et al., 2016; Karwowska et al., 2014; Xia et al., 2017; Willscher et al., 2007; Shah et al., 2015; Ilyas et al., 2010; Xiang et al., 2010; Zhu et al.,2011) heterotrophic bacteria Chromobacterium violaceum (Faramarzi et al., 2004; Chi et al., 2011) and mould fungus Aspergillus niger (Jadhav et al., 2016; Brandl et al., 2001; Faraji et al., 2018; Kolenčík et al., 2013; Hołda and Krawczykowska, 2020), Penicillium sp. (Ilyas and Lee, 2013; Brandl et al., 2001) and Rhizopus sp. (Netpae and Suckley, 2019).

Mesophilic Acidithiobacillus ferrooxidans bacteria were used for the study presented in this paper due to their extremely extensive metabolic capabilities (Fig. 1). They are extreme and obligatory acidophiles, deriving chemiosmotic energy from the naturally occurring large transmembrane $\mathrm{pH}$ gradient (extracellular $\mathrm{pH}$ typically 1.5-3.0 and intracellular $\mathrm{pH}$ - 6.5). Most strains grow optimally at $\mathrm{pH} 2$ and have a minimum growth $\mathrm{pH}$ of 1.3 . As chemolithoautotrophic organisms, they use only inorganic electron donors: reduced and elemental sulfur, iron $\left(\mathrm{Fe}^{2+}\right)$ and hydrogen $\left(\mathrm{H}_{2}\right)$. On the other hand, the electron acceptor can be either molecular oxygen or iron or sulfur which converts these bacteria into facultative anaerobes (Quatrini and Johnson, 2019).

\section{Mechanism of bacterial bioleaching}

Biological leaching of metals is carried out by a wide variety of microorganisms comprising three mainly groups

- chemolithotrophic prokaryotes,

- heterotrophic bacteria,

- microfungi.

Many different chemolithotrophic and organotrophic microorganisms are involved in the bioleaching of ores. For the recovery of metals from WEEE through biotechnology, studies have used both autotrophic and heterotrophic organisms. However, the fundamentally different chemistry of metals contained in sulfide ores relative to WEEE implies differences in leaching mechanisms (Isildar et al., 2019). Fig. 2 provides an overview of conventional autotrophic bioleaching of sulfide ores and heterotrophic and autotrophic bioleaching of recyclables.

\section{Autotrophic bioleaching of WEEE}

Chemolithoautotrophic organisms (mesophilic Acidithiobacillus ferrooxidans, Acidithiobacillus thiooxidans and Leptospirillum ferrooxidans and thermophilic Acidianus brierleyi, Sulfobacillus thermosulfidooxidans and Metallosphaera sedula) use atmospheric carbon dioxide $\left(\mathrm{CO}_{2}\right)$ as a carbon source and inorganic compounds such as iron $\left(\mathrm{Fe}^{2+}\right)$, elemental sulfur $\left(S^{\circ}\right)$ and/or reduced sulfur compounds as an energy source. In addition, most of them display tolerance to high concentrations of toxic heavy metals, making them an ideal group for processing various polymetallic sources. It should be however noted that autotrophs cannot grow directly as a result of oxidation/ dissolution of the WEEE matrix - they need an additional energy source for autotrophic growth, which may be the addition of pyrite to the leaching mixture. Microbial oxidation of sulfide minerals will result in the production of acidity and iron ions, which in turn can extract metals from WEEE, leaving the non-metallic fraction intact (Isildar et al., 2019).

Biological leaching of metals from WEEE is synergistically supported by both biogenic sulfuric acid and iron ions and relies on acidolysis and redoxolysis mechanisms.

In the presence of iron, considered as a potential energy source for microorganisms, biooxidation of Fe(II) ions to $\mathrm{Fe}$ (III) occurs, which is responsible for oxidation of insoluble form of $\mathrm{Cu}_{0}$ to the soluble form of $\mathrm{Cu}^{2+}$ according to the following equations (Awashti et al., 2019): 


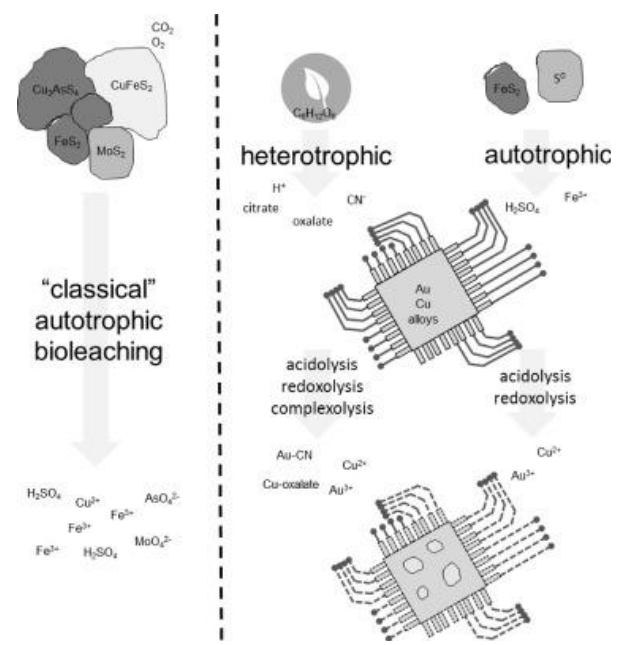

Fig. 2. Conventional autotrophic bioleaching of primary ores and heterotrophic and autotrophic bioleaching of secondary raw materials (Isildar et al., 2019) Rys. 2. Konwencjonalne autotroficzne bioługowanie rud oraz heterotroficzne i autotroficzne bioługowanie surowców wtórnych (Isildar et al., 2019)

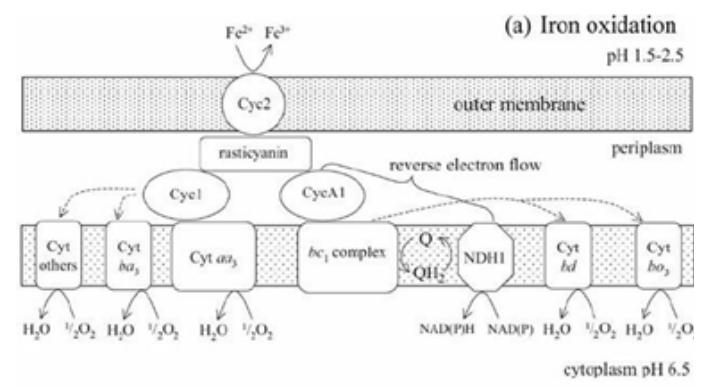

(b) Sulphur oxidation

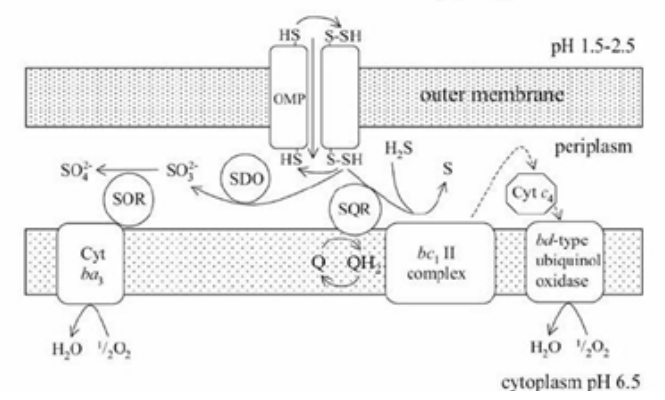

Fig. 3. Model of the iron (a) and sulfur (b) oxidation electron transport pathways at A. ferrooxidans (Karthik et al., 2014) Rys. 3. Modele utleniania a) żelaza b) siarki w łańcuchu transportu elektronów u A. ferroxidans (Karthik et al., 2014)

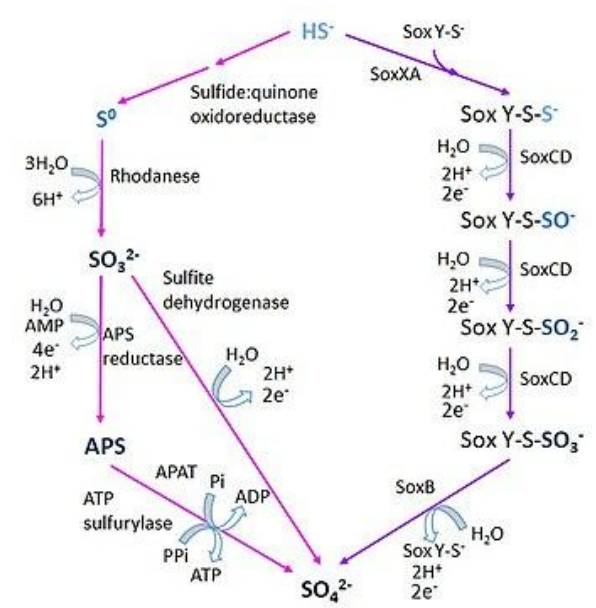

Fig. 4. Enzymatic pathways used by sulfide-oxidizing microorganisms (Poser et al., 2014)

Rys. 4. Szlaki enzymatyczne wykorzystywane przez bakterie siarkowe (Poser et al., 2014) 
$2 \mathrm{Fe}^{2+}+1 / 2 \mathrm{O}_{2}+2 \mathrm{H}^{+} \mathrm{Fe}$-oxidasiers $\rightarrow 2 \mathrm{Fe}^{3+}+\mathrm{H}_{2} \mathrm{O}$ (Microbial)

$2 \mathrm{Fe}^{3+}+\mathrm{Cu}^{0} \rightarrow 2 \mathrm{Fe}^{2+}+\mathrm{Cu}^{2+} \Delta \mathrm{G}^{\mathrm{o}}=82,9 \mathrm{~kJ} / \mathrm{mol}$ (Chemical)

The biooxidation of $\mathrm{Fe}(\mathrm{II})$ to $\mathrm{Fe}(\mathrm{III})$ is an acid consuming reaction, so the addition of acid during the bioleaching process is required to control the reaction. It also prevents the unwanted precipitation of iron. The bioleaching rate depends primarily on the initial $\mathrm{pH}$, the initial $\mathrm{Fe}^{2+}$ ion concentration, and the rate of oxidation of $\mathrm{Fe}$ (II) ions to $\mathrm{Fe}$ (III). The concentration of biogenic $\mathrm{Fe}^{3+}$ is directly correlated with the leaching rate of the leached metal as a function of time and the total extraction efficiency (Bas et al., 2013).

Copper extraction can also occur in the absence of iron by using elemental or reduced sulfur as an energy source (Fig. 3 and 4). In this process, carried out under aerobic conditions, the protons formed are responsible for the solubilization of copper with zero valence according to the equation (Awashti et al., 2019):

$\mathrm{S}^{0}+1,5 \mathrm{O}_{2}+\mathrm{H}_{2} \mathrm{O} \rightarrow \mathrm{SO}_{4}^{2-}+2 \mathrm{H}^{+}$(Microbial)

$4 \mathrm{H}^{+}+2 \mathrm{Cu}^{0}+\mathrm{O}_{2} \rightarrow 2 \mathrm{H}_{2} \mathrm{O}+2 \mathrm{Cu}^{2+}$ (Chemical)

Solubilization of metals such as $\mathrm{Al}, \mathrm{Ni}$ and $\mathrm{Zn}$ depends on mechanisms consistent with their thermodynamic reactions given below (Awashti et al., 2019):

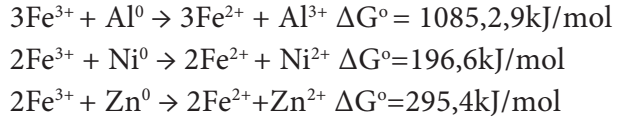

The efficiency of the metal bioleaching process from WPCBs can be increased by externally supplying iron(II) and sulfur to the culture medium especially for low iron content wastes (Lambert et al., 2015; Latorre et al., 2016; Ilyas et al. 2013). This can be explained by the partial compensation of acid consumption through S0 oxidation, which creates more suitable conditions for the bacteria.

\section{Heterotrophic bioleaching of WEEE}

Bacteria (Pseudomonas strains such as P . aeruginosa, P. fluorescens and P. putida and Chromobacterium violaceum), archaeons and fungi(Aspergillus niger, Penicillium simplicissimum) are involved in the heterotrophic bioleaching of metals. Heterotrophic microorganisms can tolerate high $\mathrm{pH}$ as well as metals complexed in the solution. Furthermore, compared to acidophiles, heterotrophs tolerate a wider $\mathrm{pH}$ range and can be used to treat moderately alkaline wastes. Heterotrophic bacteria and fungi contribute to bioleaching either by biosynthesis of organic acids (acetic, lactic, formic, oxalic, citric, succinic and gluconic acids) or production of cyanides which solubilize metals. Cyanogenic bioleaching targets precious metals and platinum group metals (PGMs), i.e. $\mathrm{Au}, \mathrm{Ag}$, $\mathrm{Pt}, \mathrm{Pd}, \mathrm{Rh}$, and $\mathrm{Ru}$, which often cannot be leached with mineral acids (Isildar et al., 2019).

\section{Materials and methods Pretreatment of WPCBs}

Printed circuit boards were separated from mobile phones manually and then crushed in a hammer mill. Three-stage shredding was performed. The first stage involved shredding using a $15 \mathrm{~mm}$ sieve. The shredded material was classified on a $1 \mathrm{~mm}$ sieve. Sieving resulted in obtaining a final product with a grain size of $0-1 \mathrm{~mm}$ and retained with a grain size $>1 \mathrm{~mm}$, which was put back to the mill. Before the second stage, the sieve was changed to a $5 \mathrm{~mm}$ one. The product was sieved, and the results were the same as in the previous stage: grain size $0-1 \mathrm{~mm}$. Grains larger than $1 \mathrm{~mm}$ were put back to the mill. In the last stage, a $1 \mathrm{~mm}$ sieve was used. Grain size was classified as $0-1 \mathrm{~mm}$. Shredding process using hammer mill made it possible to separate the grain size classes, which were subjected to further investigation. The process diagram is shown in Figure 5. During shredding, dust collectors collected dust, which, due to its low weight, constituted a ready product for examination using microorganisms. Shredded material with grain size $>1 \mathrm{~mm}$ was directed to a magnetic separator, where a magnetic and non-magnetic material were detached, which, when combined with the dust collected during the shredding process, was a source for further biological research. Next, in order to ensure sterility, the feed was cleansed using deionised water and placed in the dryer at a temperature of $80^{\circ} \mathrm{C}$ for $24 \mathrm{~h}$.

\section{Chemical analysis}

The WPCBs sample was dissolved using aqua regia and then the obtained solution was filtered and analysed for metal content using the Philips PU-9100x atomic absorption spectrophotometer. Obtained results are presented in Table 1.

To analyze the metal content of the bioleaching process, $5 \mathrm{ml}$ of leaching solution was centrifuged at $10000 \mathrm{RPM}$ for 15 minutes in order to separate the biomass and then filtered using syringe filters. The supernatant obtained in such a way was analysed for the average metal content using Philips PU9100x atomic absorption spectrophotometer.

The medium's pH change was monitored using WTW InoLab ${ }^{\circledR}$ Multi 9310.

\section{Microorganisms and growth condition}

The microorganism used for the bioleaching process was At. ferrooxidans (DSM 9464), obtained from the DSMZ Deutsche Sammlung von Mikroorganismenn und Zellkulturen $\mathrm{GmbH}$, Germany. The bacteria was initially cultured in freshly prepared DSMZ 670 medium. For activation of the culture and to achieve higher iron oxidation rate, serially five transfers were given in $9 \mathrm{~K}$ medium which contained: $44.22 \mathrm{~g}$ of $\mathrm{Fe}_{2} \mathrm{SO}_{4} \cdot 7 \mathrm{H}_{2} \mathrm{O}, 3 \mathrm{~g}$ of $\left(\mathrm{NH}_{4}\right)_{2} \mathrm{SO}_{4}, 0.5 \mathrm{~g}$ of $\mathrm{K}_{2} \mathrm{HPO}_{4}, 0.5 \mathrm{~g}$ of $\mathrm{Mg}$ $\mathrm{SO}_{4} \cdot 7 \mathrm{H}_{2} \mathrm{O}, 0.1 \mathrm{~g}$ of $\mathrm{KCl}, 0.01 \mathrm{~g}$ of $\mathrm{Ca}\left(\mathrm{NO}_{3}\right)_{2}$ per $1 \mathrm{~L}$ of distilled water. Ingredients of the medium except ferrous sulphate were sterilized in an autoclave at $121^{\circ} \mathrm{C}$ for $15 \mathrm{~min}$. Ferrous sulphate was filtered sterilized using $0.22 \mu \mathrm{m}$ membrane filter and added to the cooled sterile medium. The culture was allowed to grow till $>95 \%$ of the added ferrous iron in the medium was converted to ferric iron by the organisms. In sequential transfer, $10 \% \mathrm{v} / \mathrm{v}$ actively growing iron-oxidizing bacteria having $\sim 10^{7}$ cells $\mathrm{mL}^{-1}$ was added into a flask containing the fresh $9 \mathrm{~K}$ medium. Finally the medium in logarithmic phase of growth with approximately $20 \times 10^{7}$ cells $/ \mathrm{mL}$ as stock culture was prepared for inoculation.

\section{Bioleaching experiments}

The bioleaching experiments were carried out in one-step proces where WPCBs powder was added initially along with 


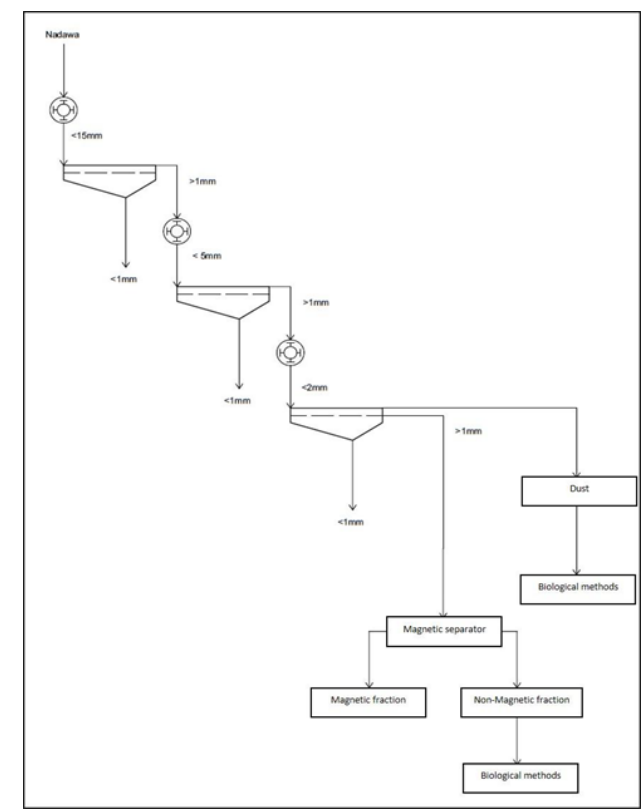

Fig. 5. Diagram of processing printed circuits board of a mobile phone

Rys. 5. Schemat przeróbki płytek drukowanych pochodzących z telefonów komórkowych

Tab. 1. Chemical analysis for metal content of WPCBs

Tab. 1. Analiza chemiczna zawartości metali w odpadach PCBs

\begin{tabular}{|c|c|}
\hline Metal type & Metal content (\%w/w) \\
\hline $\mathrm{Al}$ & 0,36 \\
$\mathrm{Cu}$ & 14,76 \\
$\mathrm{Ag}$ & 0,0012 \\
\hline
\end{tabular}

the culture and the culture was allowed to grow in the presence of e-waste. Bioleaching experiments were carried out in Erlenmeyer flasks of $500 \mathrm{ml}$ capacity, by using a incubator shaker Lab Companion IST-3075 at $150 \mathrm{rpm}$ and $30^{\circ} \mathrm{C}$. $9 \mathrm{~K}$ medium was used in all biological experiments as a leaching solution. Samples used had the volume of $200 \mathrm{ml}$. The decrease in volume due to evaporation was compensated by the addition of sterile distilled water. Effect of medium $\mathrm{pH}$ (1.5, 1.8, 2.0, 2.5 and 3.0); effect of pulp density $(1,5,10 \% \mathrm{w} / \mathrm{v})$ and effect of inoculum doses $(10,20,50 \%)$ were studied.

\section{Influence of $\mathrm{pH}$ on bioleaching and bacterial growth}

In order to investigate the influence of $\mathrm{pH}$ on bacterial growth, A. ferrooxidans stock culture were inoculated into $9 \mathrm{~K}$ medium at volume dose of $20 \%(\mathrm{v} / \mathrm{v})$ with different medium $\mathrm{pH}(1.5,1.8,2.0,2.5$ and 3.0). The population dynamics study of the microorganisms was carried out by measuring of microbial cells concentration with McFarland densitometer DEN-1.

In order to investigate the influence of $\mathrm{pH}$ on bioleaching, $2 \mathrm{~g}$ of WPCB powder (PD 1\% w/v) were placed into four 500 $\mathrm{ml}$ conical flasks which contained $200 \mathrm{ml}$ of $9 \mathrm{~K}$ medium. The $\mathrm{pH}$ of solution was adjusted to 1.5, 1.8, 2.0, 2.5 and 3.0 by adding $1 \mathrm{~N} \mathrm{H}_{2} \mathrm{SO}_{4}$. A. ferrooxidans bacteria was injected into the solution at quantity of $20 \%(\mathrm{v} / \mathrm{v})$. The variations of $\mathrm{pH}$ and concentrations of metals in solution were measured with time. Experiments were carried out for 14 days in duplicate and the averaged results reported.

Influence of pulp density (PD) on bioleaching
A. ferrooxidans stock culture were inoculated into $9 \mathrm{~K}$ medium at volume dose of $20 \%(\mathrm{v} / \mathrm{v})$ with different pulp densities (PD 1, 5, 10\% w/v). The solution $\mathrm{pH}$ was controlled at 2.0 by adding $1 \mathrm{~N} \mathrm{H}_{2} \mathrm{SO}_{4}$. The variations of $\mathrm{pH}$, the oxidation-reduction potential (ORP), and concentrations of metals in the solution were measured with time. Experiments were carried out for 14 days in duplicate and the averaged results reported.

\section{Onfluence of inoculum doses (ID) on bioleaching}

A. ferrooxidans stock culture were inoculated into $9 \mathrm{~K}$ medium at volume doses of $10 \%, 20 \%$, and $50 \%(\mathrm{v} / \mathrm{v})$. Mass of waste was constant equal to $2 \mathrm{~g}$ (PD $1 \% \mathrm{w} / \mathrm{v})$. One flask was not inoculated as a sterile control test. The solution $\mathrm{pH}$ was controlled at 2.0 by adding $1 \mathrm{~N} \mathrm{H}_{2} \mathrm{SO}_{4}$. The variations of $\mathrm{pH}$, the oxidation-reduction potential (ORP), and concentrations of metals in the solution were measured with time. Experiments were carried out for 14 days in duplicate and the averaged results reported.

\section{Result and discusion}

No Ag was detected in any leachate.

\section{Effect of medium $p H$}

Figure 6 shows the effect of different $\mathrm{pH}$ values on bacterial growth and activity. The results show that the appropriate $\mathrm{pH}$ value is in the range of 1.8-2.5, and the bacterial cell concentration is highest when the $\mathrm{pH}$ value is 2.0. Bacterial activity is inhibited outside the range of $\mathrm{pH}$ values 1.8-2.5. Therefore, exceeding the upper $\mathrm{pH}$ limit can significantly reduce microbial activity and thus slow down the bioleaching kinetics. 


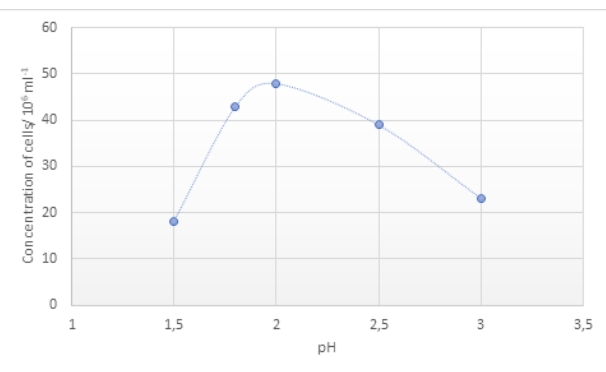

Fig. 6. Effect of $\mathrm{pH}$ on activity of bacteria Rys. 6. Wpływ pH na aktywność bakterii

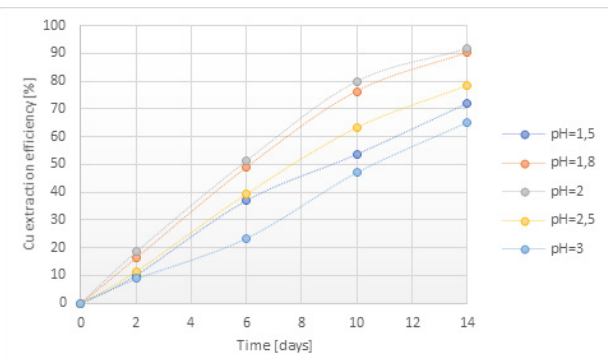

Fig. 7. Influence of $\mathrm{pH}$ on Cu extraction by A. ferrooxidans; PD 1\% w/v; ID 20\% v/v Rys. 7. Wpływ pH na ekstrakcję Cu przez A. ferrooxidans; PD 1\% w/v; ID 20\% v/v

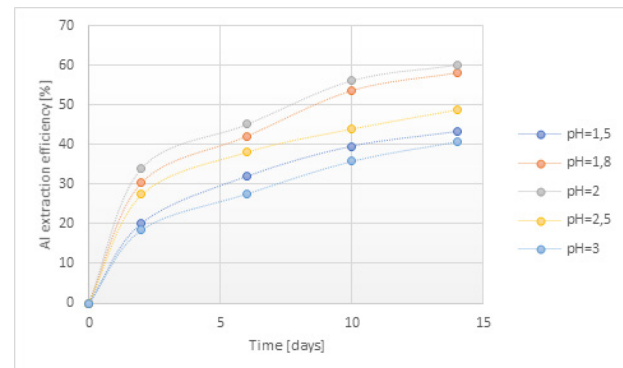

Fig. 8. Influence of $\mathrm{pH}$ on $\mathrm{Al}$ extraction by A. ferrooxidans; PD 1\% w/v; ID 20\% v/v Rys. 8. Wpływ pH na ekstrakcję Al przez A. ferrooxidans; PD 1\% w/v; ID 20\% v/v

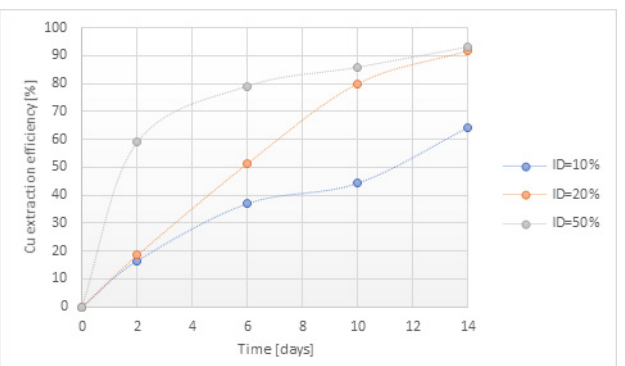

Fig. 9. Effect of inoculum dose on bioleaching process of Cu solubilisation, PD 1\% w/v Rys. 9. Wpływ dawki inokulum na proces bioługowania Cu, PD 1\% w/v

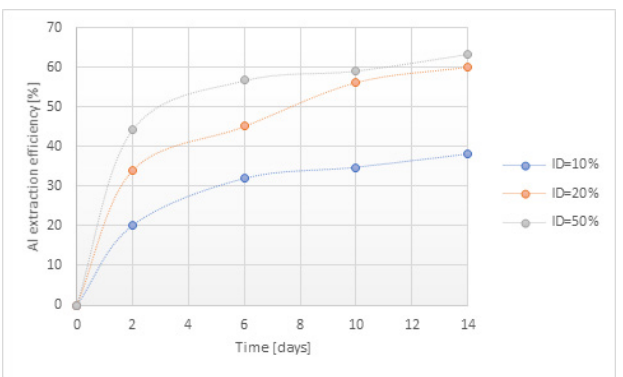

Fig. 10. Effect of inoculum dose on bioleaching process of Al solubilisation, PD 1\% w/v Rys. 10. Wpływ dawki inokulum na proces bioługowania $\mathrm{Cu}, \mathrm{PD} 1 \% \mathrm{w} / \mathrm{v}$ 


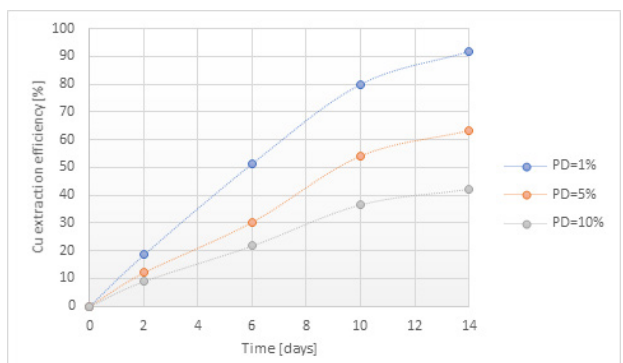

Fig. 11. Effect of pulp density on bioleaching process of Cu solubilisation, ID $20 \% \mathrm{v} / \mathrm{v}$ Rys. 11. Wpływ gęstości zawiesiny na proces bioługowania Cu, ID 20\%\% v/v

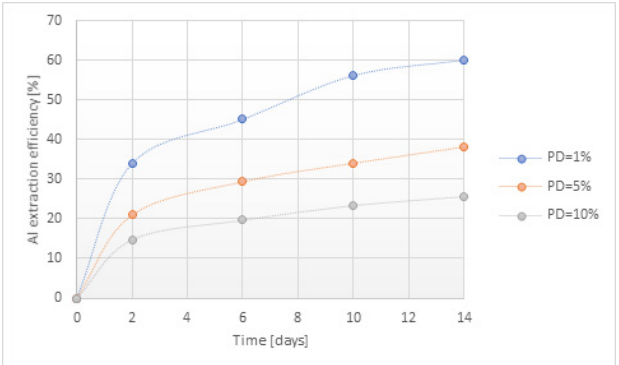

Fig. 12. Effect of pulp density on bioleaching process of Al solubilisation, ID $20 \% \mathrm{v} / \mathrm{v}$ Rys. 12. Wpływ gęstości zawiesiny na proces bioługowania Al, ID 20\%\% v/v

Since bacterial activity is closely dependent on $\mathrm{pH}$, therefore $\mathrm{pH}$ correction is very important for the biological leaching of WPCBs, a phenomenon to which other researchers have also pointed out in their work (Yang et al., 2014; Willner and Fornalczyk, 2013; Garg et al., 2019). In the bioleaching process, the consumption of $\mathrm{H}^{+}$ions resulting in an elevated $\mathrm{pH}$ can have direct and indirect causes. Direct wear is due to reaction with alkaline substances and metals in the WPCB matrix while indirect wear is due to natural and bacterial oxidation of $\mathrm{Fe}^{2+}$. What is also noteworthy, during the bioleaching process, a decrease in $\mathrm{pH}$ and a decrease in leaching agent concentration may occur due to the precipitation of jarosite according to the following equation, where $\mathrm{A}^{+}$is a monovalent cation (Hubau et al., 2020):

$\left.\mathrm{A}^{+}+3 \mathrm{Fe}^{3+}+2 \mathrm{SO}_{4}^{2-}+6 \mathrm{H}_{2} \mathrm{O} \rightarrow \mathrm{AFe}_{3}\left(\mathrm{SO}_{4}\right)_{2} \mathrm{OH}\right)_{6}+6 \mathrm{H}^{+}$

Diagrams 7 and 8 show the effect of initial system $\mathrm{pH}$ on bioleaching of metals from WPCBs

Biological leaching of metals from WPCBs is synergistically promoted by both sulfuric acid and iron ions. In the absence of elemental or reduced sulfur, the primary mechanism for metal bioextraction is redoxolysis using biooxidation of $\mathrm{Fe}$ (II) ions to $\mathrm{Fe}$ (III) as an energy source for microorganisms. The resulting leaching agent is a strong oxidant that reacts with metals in the waste. Therefore, during bioleaching, sufficient $\mathrm{FeSO}_{4}$ should be present in the medium just to initiate the chain of biological transformations, since, during the process, $\mathrm{FeSO}_{4}$ is reconstituted through the chemical oxidation of solubilized metals which reduces ferric iron back to ferrous iron. The resulting iron(II) ions are reused as an energy source. As can be seen, without bacteria or iron(II) ions, the regeneration cycle cannot continue, which affects the leaching efficiency. Additionally, the iron regeneration cycle requires the presence of $\mathrm{H}^{+}$ions, which means that the metal bioleach- ing efficiency is also closely related to $\mathrm{pH}$. The results of the study showed a close relationship between the initial $\mathrm{pH}$ and the degree of metal leaching, which is related to the effect of $\mathrm{pH}$ on bacterial growth and metabolic activity.

Graph analysis shows that the highest metal leaching efficiency, for $\mathrm{Cu} 90.23 \%$ and $\mathrm{Al} 60.23 \%$, was observed at an initial $\mathrm{pH}$ of 2.0. However, it should be noted that the results for an initial $\mathrm{pH}$ value of 1.8 show little difference. At $\mathrm{pH} 1.5,1.8$, $2.0,2.5$ and 3.0 , the extraction rate of copper was, respectively, $72.11 ; 90.23 ; 91.68 ; 78.35 ; 65.24 \%$, while that of aluminum was $43.18 ; 58.12 ; 60.23 ; 48.95 ; 40.67$, respectively. The reduction in extraction efficiency is due to several factors. Outside the range of 1.8-2.5, it is due to disruption of microbial growth, while at $\mathrm{pH} 2.5$ and 3.0, it is due to metal precipitation, low iron(III) solubility and formation of jarosite. Similar observations have also been made by other researchers (Yang et al., 2014; Khatri et al., 2018; Garg et al., 2019).

\section{Effect of Inoculum dose}

The effect of microbial dose on metal leaching rate is shown in Figures 9 and 10.

The following extraction efficiencies were obtained during 14 days of the process depending on inoculum doses of 10 , $20,50 \%$ for $\mathrm{Cu}: 64.21 ; 91.68 ; 93.12 \%$, respectively, while for Al: $38.12 ; 60.23 ; 63.44$. As can be seen, a higher dosage of bacterial cultures accelerates the metal extraction process due to an increase in the concentration of the leaching agent in the solution. It is also important to note the comparable final extraction efficiencies for inoculum doses of 20 and 50\%, which means that high extraction efficiencies can be achieved with a lower initial dose of microorganisms.

\section{Effect of pulp density}

Diagrams 11 and 12 show the effect of suspension density on the metal bioleaching process. 
The study showed a decrease in metal extraction with increasing pulp density. The metal extraction efficiencies for pulp density $1 ; 5 ; 10 \%$ are 91,$68 ; 63,22 ; 42,11 \%$ for $\mathrm{Cu}$ and 60,$23 ; 3823 ; 25,55 \%$ for $\mathrm{Al}$, respectively. This can be explained by a number of factors. Firstly, high suspension density involves increased concentrations of metals and matrix components that can be toxic to unadapted microorganisms. On the other hand, the WPCB matrix may contain alkaline substances such as reactive metals and organic substances which may increase acid consumption by raising the $\mathrm{pH}$, thus inhibiting microbial growth and promoting $\mathrm{Fe} 3+$ consumption in the hydrolysis reaction. The effect of pulp density on the bioleaching process has also been noted by other researchers (Yang et al., 2014; Khatri et al., 2018; Garg et al., 2019), leveling it by adapting the bacteria to increasing waste concentrations.

\section{Conclusions}

Technological innovations and increased demand for electronic devices resulted in production of more and more waste with high metal content. This means that e-waste recycling is not only beneficial for waste neutralisation but also for the recovery of metals, including precious and rare-earth metals. Traditional e-waste recycling techniques, namely pyrometallurgical and hydrometallurgical techniques, are eco-unfriendly, energy-intensive, and noneconomic. This posed a challenge of using biotechnology to process e-waste and recover metals in an economical and environmentally friendly way. Closing the consumer cycle by recovering metals from diluted and complex waste streams will become increasingly economically viable. In addition, increasingly stringent envi- ronmental regulations and restrictions will drive demand for new methods to recycle and recover metals, especially PGMs (platinum group metals) and REEs (rare earth elements) from waste streams, providing an ideal niche for biometallurgy. The advantages of microbial processes are their specific nature, energy efficiency and minimal new waste creation. Current microbial processes face challenges associated with complex waste streams, toxicity, and competing side reactions.

The research presented in the article aimed at assessing the usefulness of the biotechnological method for leaching of selected metals from e-waste. The results indicate that it is possible to mobilize metals from WPCBs using microorganisms such as Acidithiobacillus ferroxidans bacteria. For some elements, almost complete solubilization was achieved but it can be noted that in order to recover as much metal as possible, it should be an autotrophic/heterotrophic two-step process. In the first step, bacteria can be used to solubilize $\mathrm{Cu}, \mathrm{Al}$, and in the second step, heterotrophic mold fungi can be used for selective Ag removal (Hołda and Krawczykowska, 2020).

A decrease in metal bioleaching efficiency with increasing pulp density due to direct contact of bacterial cells with the waste material containing toxic fractions is definitely a bottleneck in the up-scaling process. This impact can be reduced through adaptation of microorganisms or by using a separate process in which cells grow without waste (Arshadi and Mousavi, 2014; Arshadi et al., 2021; Ilyas et al., 2013). Nonetheless, the application of biotechnological methods on an industrial scale requires further research in order to eliminate discrepancies concerning process parameters present in the literature and optimize those parameters.

\section{Literatura - References}

1. Akcil A., Erust C., Gahan C.S., Ozgun M., Sahin M., Tuncuk A., 2015. Precious metal recovery from waste printed circuit boards using cyanide and non-cyanide lixiviants--A review. Waste Management, 45, 258-271

2. Arshadi M., Mousavi S.M., 2014. Simultaneous recovery of $\mathrm{Ni}$ and $\mathrm{Cu}$ from computer-printed circuit boards using bioleaching: Statistical evaluation and optimization. Bioresource TechnologyVol. 174, Pages 233-242

3. Arshadi M., Pourhossein F., Mousavi S.M., Yaghmaei S., 2021. Green recovery of Cu-Ni-Fe from a mixture of spent PCBs using adapted A. ferrooxidans in a bubble column bioreactor. Separation and Purification Technology, 118701

4. Awasthi A.K., Hasan M., Mishra Y.K., Pandey A.K., Tiwary B.N., Kuhad R.C., Gupta V.K., Thakur V.K., 2019. Environmentally sound system for E-waste: Biotechnological perspectives. Current Research in Biotechnology, 1, 58-64

5. Bas A.D., Deveci H., Yazici E.Y., 2013. Bioleaching of copper from low grade scrap TV circuit boards using mesophilic bacteria. Hydrometallurgy 138, 65-70

6. Blažek V., Závada J., Bouchal T., Lébr J., Fečko P.,2012. Leaching of Copper and Tin from Electronic Waste Using Acidithiobacillus ferrooxidans. Journal of the Polish Mineral Engineering Society, No 1(28), p. 1-7.

7. Bosecker K., 2006. Bioleaching: metal solubilization by microorganisms. FEMS Microbiol. Rev., 20, pp. 591-604

8. Brandl H., Bosshard R., Wegmann H., 2001. Computer-munching microbes: metal leaching from electronic scrap by bacteria and fungi. Hydrometallurgy, 59 (2-3), 319-326

9. Chi T.D., Lee J.C., Pandey B.D., Yoo K., Jeong J., 2011. Bioleaching of gold and copper from waste mobile phone PCBs by using a cyanogenic bacterium. Miner. Eng., 24 (11), 1219-1222

10. Cui J., Zhang L., 2008. Metallurgical recovery of metals from electronic waste: a review. Journal of Hazardous Materials, $158(2-3), 228-256$ 
11. Faraji F., Golmohammadzadeh R., Rashchi F., Alimardani N., 2018. Fungal bioleaching of WPCBs using Aspergillus niger: Observation, optimization and kinetics. Journal of Environmental Management 217, 775-787

12. Faramarzi M.A., Stagars M., Pensini E., Krebs W., Brandl H., 2004. Metal solubilization from metal-containing solid materials by cyanogenic Chromobacterium violaceum. J. Biotechnol., 113 (1-3), 321-326

13. Garg H., Nagar N., Ellamparuthy G., Angadi S.I., Gahan C.S., 2019. Bench scale microbial catalysed leaching of mobile phone PCBs with an increasing pulp density. Heliyon, vol. 5 (12)

14. Hao J., Wang Y., Wua Y., Guo F., 2020. Metal recovery from waste printed circuit boards: A review for current status and perspectives. Resources, Conservation and Recycling, 157

15. Hołda A., Krawczykowska A., 2020. Bioleaching of Selected Metals from Waste Printed Circuit Boards by Fungi. Journal of the Polish Mineral Engineering Society, 161-169

16. Hong Y., Valix M., 2014. Bioleaching of electronic waste using acidophilic sulfur oxidising bacteria. Journal of Cleaner Production 65, 465-472

17. Hubau A., Minier M., Chagnes A., Joulian C., Silvente C., Guezennec A-G., 2020. Recovery of metals in a double-stage continuous bioreactor for acidic bioleaching of printed circuit boards (PCBs). Separation and Purification Technology, Vol. 238

18. Ilyas S., Lee J.C., 2013. Fungal leaching of metals from electronic scrap. Miner. Metall. Process., 30 (3), 151-156

19. Ilyas S., Lee J-c., Chi R-a., 2013. Bioleaching of metals from electronic scrap and its potential for commercial exploitation. Hydrometallurgy, Vol. 131-132, 138-143

20. Ilyas S., Ruan C., Bhatti H.N., Ghauri M.A., Anwar M.A., 2010. Column bioleaching of metals from electronic scrap. Hydrometallurgy, 101 (3-4), 135-140

21. Iş̧1lar A., van Hullebusch E.D., Lenz M.,Du Laing G., Marra A., Cesaro A., Panda S., Akcil A., Kucuker M.A., Kuchta K., 2019. Biotechnological strategies for the recovery of valuable and critical raw materials from waste electrical and electronic equipment (WEEE) - A review. Journal of Hazardous Materials, Vol. 362, 467-481

22. Jadhav U., Su C., Hocheng H. 2016. Leaching of metals from printed circuit board powder by an Aspergillus niger culture supernatant and hydrogen peroxide. RSC Adv., 6 (49), 43442-43452

23. Karthik O., Rajasekar A., Balasubramanian R., 2014. Bio-Oxidation and Biocyanidation of Refractory Mineral Ores for Gold Extraction: A Review. Critical Reviews in Environmental Science and Technology 45(15)

24. Karwowska E., Andrzejewska-Morzuch D., Lebkowska M., Tabernacka A., Wojtkowska M., Telepko A., Konarzewska A. 2014. Bioleaching of metals from printed circuit boards supported with surfactant-producing bacteria. J. Hazard. Mater., 264, 203-210

25. Kaya, M., 2017. Recovery of metals and nonmetals from waste printed circuit boards (PCBs) by physical recycling techniques. Energy Technology, pp. 433-451

26. Khatri B.R., Sodha A.B., Shah M.B., Tipre D.R., Dave S.R., 2018. Chemical and microbial leaching of base metals from obsolete cell-phone printed circuit boards. Sustainable Environment Research, Vol. 28, 6, 333-339

27. Kolenčík M., Urík M., Čerňanský S., Molnárová M., Matúš P., 2013. Leaching of Zinc, Cadmium, Lead and copper from electronic scrap using organic acids and the Aspergillus Niger strain. Fresenius Environmental Bulletin 22 (12)

28. Krebs W., Brombacher C., Bosshard P., Bachofen R., Brandl H., 2006. Microbial recovery of metals from solids. FEMS Microbiol. Rev., 20, pp. 605-617

29. Lambert F., Gaydardzhiev S., Léonard G., Lewis G., Bareel P.F., Bastin D., 2015. Copper leaching from waste electric cables by bio-hydrometallurgy. Mineral Engineering, 76, pp. 38-46

30. Latorre M., Cortés M.P., Travisany D., Di Genova A., Budinich M., Reyes-Jara A., Hödar C., González M., Parada P., Bobadilla-Fazzini R.A., Cambiazo V., Maass A., 2016. The bioleaching potential of a bacterial consortium. Bioresource Technology, 218, pp. 659-666

31. Li H., Eksteen J., Oraby E., 2018. Hydrometallurgical recovery of metals from waste printed circuit boards (WPCBs): Current status and perspectives - A review. Resources, Conservation and Recycling, 139, 122-139

32. Lu Y., Zhenming X., 2016. Precious metals recovery from waste printed circuit boards: a review for current status and perspective. Resour. Conserv. Recycl., 113, 28-39

33. Netpae T., Suckley S., 2019. Bioleaching of $\mathrm{Cu}$ and $\mathrm{Pb}$ from printed circuit boards by Rhizopus oligosporus and Aspergillus Niger. Environmental and Experimental Biology, 17, 85-89

34. Pollmann K., Kutschke S., Matys S., Raff J., Hlawacek G., L.Lederer F., 2018. Bio-recycling of metals: Recycling of technical products using biological applications. Biotechnology Advances 36(4), 1048-1062 
35. Poser A., Vogt C., Knöller K., Ahlheim J., Weiss H., Kleinsteuber S., Richnow H. H., 2014. Stable sulfur and oxygen isotope fractionation of anoxic sulfide oxidation by two different enzymatic pathways. Environmental science \& technology, 48(16), 9094-9102

36. Quatrini R., Johnson D.B., 2019. Acidithiobacillus ferrooxidans. Trends in Microbiology, Vol. 27, No. 3

37. Sethurajan M., Gaydardzhiev S., 2021. Bioprocessing of spent lithium ion batteries for critical metals recovery - A review. Resources, Conservation and Recycling, Vol. 165

38. Shah M.B., Tipre D.R., Purohit M.S., Dave S.R., 2015. Development of two-step process for enhanced biorecovery of $\mathrm{Cu}-\mathrm{Zn}-\mathrm{Ni}$ from computer printed circuit boards. J. Biosci. Bioeng., 120 (2), 167-173

39. Tipre D.R,. Khatri B.R., Thacker S.C., Dave S.R., 2021. The brighter side of e-waste-a rich secondary source of metal. Environmental Science and Pollution Research, 28:10503-10518

40. Valdés J., Pedroso I., Quatrini R., Dodson R.J., Tettelin H., Blake II R., Eisen J.A., Holmes D.S., 2008. Acidithiobacillus ferrooxidans metabolism: from genome sequence to industrial applications. BMC Genomics, 9:597

41. Wang S., Zheng Y., Yan W., Chen L., Mahadevan G.D., Zhao F., 2016. Enhanced bioleaching efficiency of metals from e-wastes driven by biochar. J. Hazard. Mater., 320, 393-400

42. Willner J., Fornalczyk A., 2013. Extraction of metals from electronic waste by bacterial leaching. Environment protection engineering, vol. 39, no. 1

43. Willscher S., Katzschner M., Jentzsch K., Matys S., Pollmann H., 2007. Microbial leaching of metals from printed circuit boards. Adv. Mater. Res., 20-21, 99-102

44. Xia M., Bao P., Liu A., Wang M., Shen L., Yu R., Liu Y., Chen M., Li J., Wu X., Qiu G., Zeng W., 2018. Bioleaching of low-grade waste printed circuit boards by mixed fungal culture and its community structure analysis. Resources, Conservation and Recycling, 136, 267-275

45. Xia M.C., Wang Y.P., Peng T.J., Shen L., Yu R.L., Liu Y.D., Chen M., Li J.K., Wu X.L., Zeng W.M., 2017. Recycling of metals from pretreated waste printed circuit boards effectively in stirred tank reactor by a moderately thermophilic culture. J. Biosci. Bioeng., 123 (6), 714-721

46. Xiang Y., Wu P., Zhu N., Zhang T., Liu W., Wu J., Li P., 2010. Bioleaching of copper from waste printed circuit boards by bacterial consortium enriched from acid mine drainage. J Hazard Mater 184, 812-818

47. Yang Y., Chen S., Li S., Chen M., Chen H., Liu B., 2014. Bioleaching waste printed circuit boards by Acidithiobacillus ferrooxidans and its kinetics aspect. Journal of Biotechnology, Vol. 173, 24-30

48. Zhang Y., Liu S., Xie H., Zeng X., Li J., 2012. Current Status on Leaching Precious Metals from Waste Printed Circuit Boards. Procedia Environmental Sciences, 16, 560-568

49. Zhu N., Xiang Y., Zhang T., Wu P., Dang Z., Li P., Wu J., 2011. Bioleaching of metal concentrates of waste printed circuit boards by mixed culture of acidophilic bacteria. J. Hazard Mater 192, 614-619

50. Zhuang W.Q., Fitts J.P., Ajo-Franklin C.M., Maes S., Alvarez-Cohen L., Hennebe T., 2015. Recovery of critical metals using biometallurgy. Curr. Opin. Biotechnol. 33, 327-335

\section{Ekstrakcja wybranych metali z odpadowych obwodów drukowanych w procesie bioługowania bakteriami}

Szybki rozwój technologiczny i wzrost popytu na urządzenia elektroniczne prowadzą do powstawania coraz większej ilości odpadów o dużej zawartości metali. Na calym świecie każdego roku wytwarza się 50 milionów ton odpadów elektronicznych (WEEE). Biorąc pod uwage zawartość metali w nich obecnych, uważa się je za urban mining i jeśli zostanq one odpowiednio przetworzone, moga stużyć jako alternatywne, wtórne źródło metali. Szczególne znaczenie mają odpadowe obwody drukowane (WPCBs) stanowiące 3-5\% WEEE. Zawierają one średnio 30-40\% wagowych metali, o czystości większej niż w minerałach. Mając na uwadze korzyści środowiskowe i ekonomiczne, coraz większa uwagę przywiązuje się do rozwoju procesów odzyskiwania metali i innych cennych materiałów $z$ odpadów PCBs. Badania przedstawione $w$ artykule miały na celu ocenę przydatności metody biotechnologicznej do ługowania wybranych metali z odpadów elektronicznych. Wyniki wskazuja, że jest możliwe mobilizowanie metali z PCBs przy użyciu mikroorganizmów takich jak bakterie Acidithiobacillus ferroxidans.

Słowa kluczowe: Acidithiobacillus ferrooxidans,, bioługowanie, odpadowe obwody drukowane, WPCBs 